\title{
Investigation and Detection of Fire Blight Disease on Pear Caused by Erwinia amylovora in Erbil Province
}

\author{
Tahsein A.M. Amein \\ Ramadan Y. Mohamed* \\ Department of Plant Protection/College of Agriculture/Salahaddin University/ Erbil \\ Aram N. Hussein \\ Department of Plant Protection/Erbil Polytechnic University/ Technical Institute of Khabat
}

(Received 17/2/2019;Accepted 20/5/2019)

\section{ABSTRACT}

Four isolates of Erwinia amylovora were isolated during (May, 2016) from different pear orchards of Erbil Governorate in Kurdistan/Iraq. Typical symptoms of fire blight such as shepherd crock and bacterial exudates were observed in pear trees, The bacteria morphologically similar to E. amylovora were isolated and characterized morphologically using selective media Crosse and Goodman, Biochemically using the API 20E and same biochemical tests (oxidase, catalase and indole) were also used for identification, and the result of API 20E kit (Biomérieux, France), demonstrated that the bacterium belongs to E. amylovora. Also all isolates were oxidase and indole negative, catalase positive and produced craters on the surface of colonies which permitted positive identification of the pathogen. A pathogenicity tests were positive on young pear shoots and immature fruits. PCR amplification was applied to identify a specific region of chromosomal pEA71, Results showed positive reaction to this specific primer. The first study conducted on pear fire blight caused by E. amylovora in Erbil Province.

Keywords: Fire blight disease, Pear, Erwinia amylovora, bacteria.

Erwinia

التحري والكشف عن مرض اللفحة النارية على العرموط (الكمثري) المتسبب عن بكتريا

amylovora

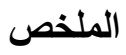

نم عزل أربع عزلات من Erwinia amylovora خلال (أيار، 2016) من مسح لبساتين العرموط في مناطق مختلفة من محافظة أربيل في كردستان / العراق. وقد لوحظت الأعراض النموذجية للفحة النارية والافرازات البكتيرية على أنثجار العرموط، حيث تم عزل البكتيريا المشابه مظهريا للبكتريا E. amylovora وتميزت بالثكل المورفولوجي باستخدام الوسط الونه

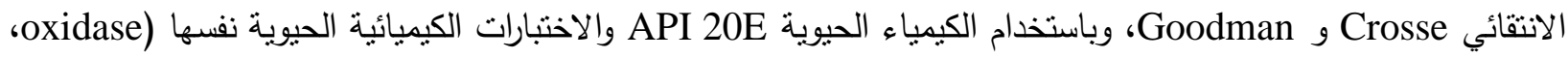
(indole و تم أيضًا تشخيص البكتريا، وأظهرت نتيجة مجموعة(API 20EBiomérieux ,France) و أن البكتيريا تتتمي إلى E. amylovora. أيضا جميع العزلات كانت سالبة لاختبار أوكسيديز وإندول، وموجبة لاختبار الكاتاليز لوجود فقاعات على سطح المستعرات والتي تسمح بالتشخيص الايجابي للمرض. كانت اختبارات الإمراضية إيجابية على براعم الكمثرى والثمار غير الناضجة. نم تأكيد التشخيص بواسطة تقنية PCR وإحداث التضاعف لمنطقة معينة من الكروموسومات pEA71 وأظهر تفاعلا إيجابيًا مع البادئ المحدد. على حد علمنا هذا هو التقرير الأول عن اللفحة النارية على العرموط الناجم عن بكتريا E. amylovora في محافظة أربيل.

الكلمات الدالة: مرض اللفحة النارية، العرموط (الكمثري)، بكتريا Erwinia amylovora. 


\section{INTRODUCTION}

Fire blight disease is known as one of the most important plant bacterial diseases worldwide, causesd by the bacterium E. amylovora (Malika et al., 2011), it is the first bacterium illustrated as a causal agent of a plant disease by Burrill in 1883. Fire blight is a destructive necrotic disease affects Malus domestica, Pyrus communis, and other Rosaceae family plants (Norelli et al., 2003).

E. amylovora is determined as one of the important plant pathogenic bacteria in molecular plant pathology (Mansfield et al., 2012). According to (Van Der Zwet, 2006), fire blight disease recorded in more than 46 countries around the world. (Kaluzana et al., 2013), reported different methods for detection of the E. amylovora including; isolation of bacteria on selective or semiselective media, tests of pathogenicity and DNA-based methods, especially Polymerase chain reaction, which offers the probability to overcome these constraints and allows fast detection of E. amylovora with high specificity and sensitivity.

\section{Field survey and samples collection}

MATERIALS AND METHODS

Samples of Pear trees (twigs including leaves and fruits) with suspected bacterial fire blight symptoms were collected from 24 orchards in different locations of Erbil Province during autumn 2015, and late spring of 2016. Samples were transferred to the laboratory of Plant Protection Dept. /Agriculture College in plastic bags as soon as possible and preserved in refrigerator at $4{ }^{\circ} \mathrm{C}$. From each orchard samples, isolation was done from different plant parts. A total number of 126 samples from symptomatic shoots, leaves and fruits were collected.

\section{Isolation and purification of bacteria from infected plant parts}

Isolates collected from infected pears (Pyrus communis L.) tissues (twigs, leaves, and fruits), showing the most suspected fire blight symptoms. Materials for processing are selected from the leading edge of disease lesions. Samples were washed in tap water. Infected tissues surface sterilized by soaking in $1 \%$ sodium hypochlorite for $3 \mathrm{~min}$., then rinsed three times in sterile distilled water and blotted dry on sterilized tissue paper. Small pieces of diseased tissues were macerated in $1 \mathrm{ml}$ of sterile phosphate buffer saline (PBS) in a plastic petri dish. The tissues were left for $30 \mathrm{~min}$. to allow the bacteria to diffuse out of the tissue. With a sterile a loop, $30 \mu 1$ of macerated tissue was streaked (EPPO,2004) onto King's medium (KB) agar (King et al., 1954).

\section{Phenotypic Identification}

To bacteria morphological and microscopic identification the following key tests were performed; gram reaction, oxidase and catalase tests (Jones and Geider, 2001), colony on 5\% sucrose nutrient agar (Billing et al., 1961) and Crosse and Goodman (CG) media (Crosse and Goodgman, 1973). The biochemical characterization of the isolates was carried out by analytic profile index (API 20E) (BioMerieux/France). The API strip was used according to the manufacturer's indications, except the temperature of incubation that was established at $26 \mathrm{C}$ for 48 h. Before starting a quick oxidase test for cytochrome enzyme was done according to manufacturer's instructions.

\section{Pathogenicity Test}

Pathogenicity test was performed on immature pear fruits and young shoots. In order to perform infections, branches with healthy shoots $(25-30 \mathrm{~cm}$ length) were placed in conical flask with water. Infections were carried out by injecting the apical bud and four stings in upper leaves with $0.1 \mathrm{ml}$ of bacterial suspension approximately $10^{7}$ to $10^{8}$ colony forming units $(\mathrm{CFU} / \mathrm{ml})$ with a hypodermic needle in the apical bud and four stings in upper leaves. For bacterial isolate, three shoots were used. For negative control shoots were inoculated only with sterile distillated 
water. The relative humidity close to $90 \%$ and the temperature in range from 27 to $30{ }^{\circ} \mathrm{C}$ were established for 8-10 days during the experiment time. Symptoms observation was recorded (Severin and Cornea, 2009). Immature pear fruits were surface sterilized with $70 \%$ ethanol then cut in transverse slices about $1.0 \mathrm{~cm}$ thick. Three slices were placed on a sterile moist filter paper in sterile petri dishes for bacterial isolate. By using hypodermic needle, $50 \mu 1$ of bacterial suspension was placed at the center of each slice. SDW was used as negative control. The slices were kept under humid conditions at $27^{\circ} \mathrm{C}$ for five days (Beer and Rundle, 1983).

\section{Genomic DNA extraction}

Genomic DNA was extracted directly on the sub-cultured colonies of the identified bacteria by Presto ${ }^{\mathrm{TM}}$ Mini g DNA Bacteria Kit from Geneaid/ UK with minor modifications.

\section{DNA amplification by (PCR)}

The specific DNA primer (pEA71) for E. amylovora was used to amplify a targeted $E$. amylovora DNA by PCR. The primers pEA71; G1-F: 5'-CCT GCA TAA ATC ACC GCT GAC AGC TCA ATG-3' and G2-R: 5'-GCT ACC ACT GAT CGC TCG AAT CAA ATC GGC-3' were obtained from specific chromosomal DNA of E. amylovora (Taylor et al., 2001), and used to amplify DNA. The pEA71 primer and components were mixed in the same amplification reaction (Table 1). Appropriate thermocycling program was set on thermocycler according to the Go Taq Green Master mix protocol for pEA71 chromosomal DNA as pre-denaturation step at $95^{\circ} \mathrm{C}$ for 3 min., Thermocycling (30 cycles): Denaturation $95^{\circ} \mathrm{C}$ for 30 seconds, Annealing 67.5 ${ }^{\circ} \mathrm{C}$ for $30 \mathrm{sec}$., Elongation $72{ }^{\circ} \mathrm{C}$ for $30 \mathrm{sec}$., Final Extension $72{ }^{\circ} \mathrm{C}$ for $5 \mathrm{~min}$. At the end of the process, amplified products were removed and stored at $-20^{\circ} \mathrm{C}$ until used for electrophoresis.

Table 1: The components required for primer pEA71 amplification

\begin{tabular}{|c|c|}
\hline Components & Volume per reaction $(\boldsymbol{\mu l})$ \\
\hline Go Taq Green Master Mix 2x & 12.5 \\
\hline G1-F Forward primer & 2.5 \\
\hline G2-R Reverse primer & 2.5 \\
\hline Sample DNA & 5 \\
\hline Deionized distilled water & 2.5 \\
\hline Total reaction volume & 25 ( volume of a single PCR reaction) \\
\hline
\end{tabular}

\section{Electrophoresis}

PCR products were separated on a $1 \%$ agarose gel in TBE buffer $(1 \mathrm{~h}$ at $80 \mathrm{~V})$, stained with ethidium bromide, the gel was viewed by UV Transilluminator and the result was photographed with digital camera (Sambrook et al., 2000).

\section{Occurrence of Bacterial Fire Blight Symptoms}

\section{RESULTS AND DISCUSSION}

Symptoms were found on fruits, stems, leaves and exudates of Pear trees in one orchard. In late spring, small droplets of sticky bacterial ooze were observed on the surface of blighted shoots Fig.(1; A). Foliage parts of pear trees were observed as scorched or burned by fire Fig. $(1 ;$ C). Shepherd's crook which is a characteristic symptom of fire blight was observed in the infected shoots Fig.(1; D). Dark small and shriveled fruits were also found on diseased branches 
Fig.(1 B). These symptoms were also observed on pear trees in Iran (Kazempor et al., 2006), Turkey (Bastas, 2014), Syria (Ammouneh et al., 2008) and Egypt (Ashmawy et al., 2015).
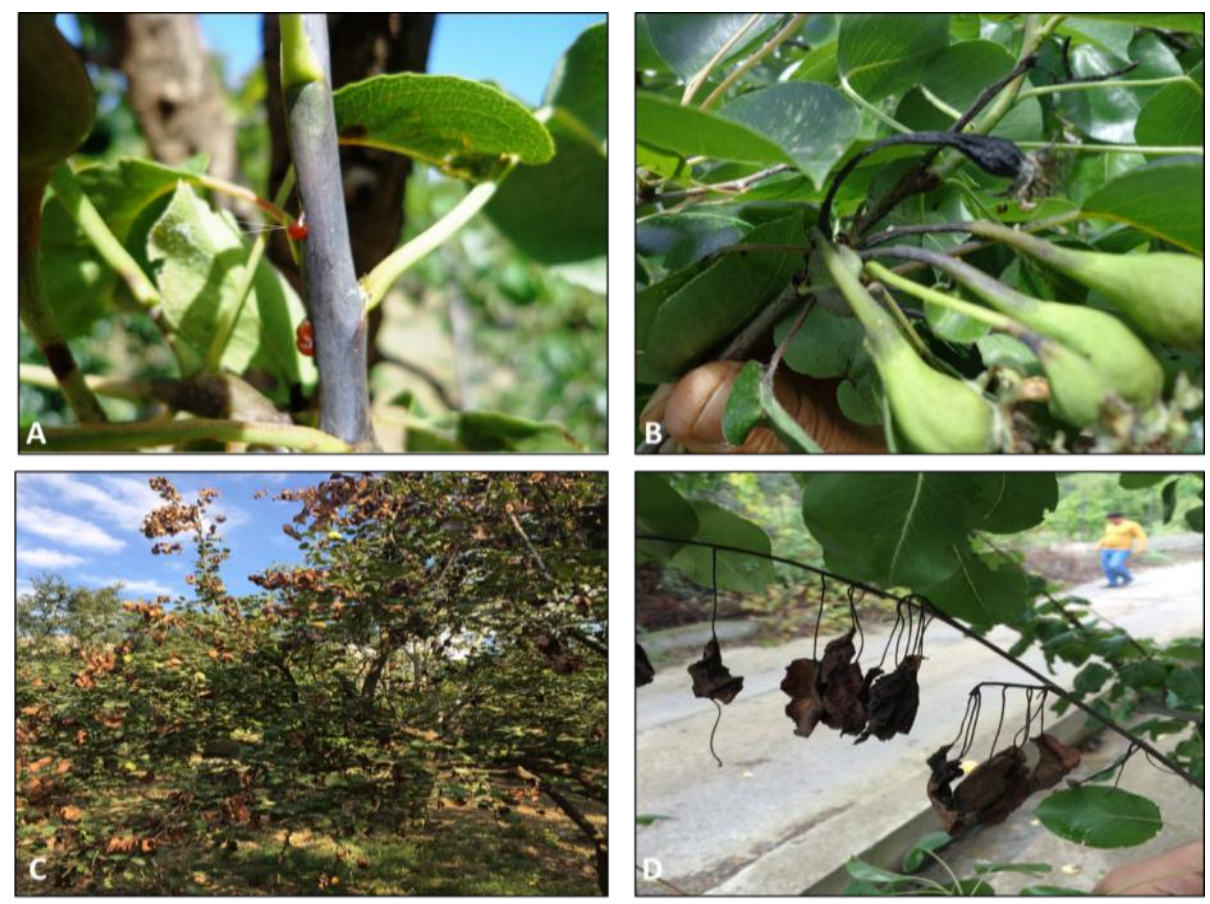

Fig. 1: Different symptoms of fire blight observed in pear orchard from Choman area of Erbil Province during collection of samples. A: Blighted shoots. B: Dark small and shriveled fruits. C: Foliage parts of pear trees. D: Shepherd's crook.

\section{Isolation and identification of E.amylovora}

Only four isolates were observed, a characteristic craters on the surface of colonies when examined at $10 \mathrm{X}$ magnification by light microscopy Fig. $(2 \mathrm{~A})$, which permitted positive identification of the pathogen. The isolates plated on sucrose nutrient agar formed only one morphological type of colonies typically white, domed, shiny, mucoid (levan type) Fig.(2B).These morphological characteristics are compatible with (Atanasova et al., 2005; Crosse and Goodman, 1973). Fire blight, caused by the Erwinia amylovora, is a common and very serious bacterial disease. The disease is also referred to as blossom blight, spur blight, fruit blight, twig blight (Anonymous, 2014).

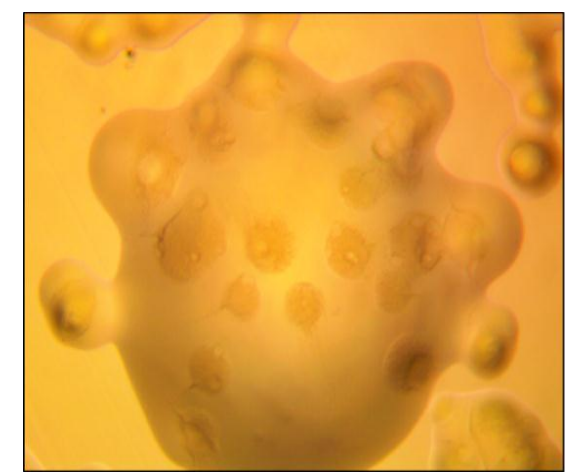

A: CG plates

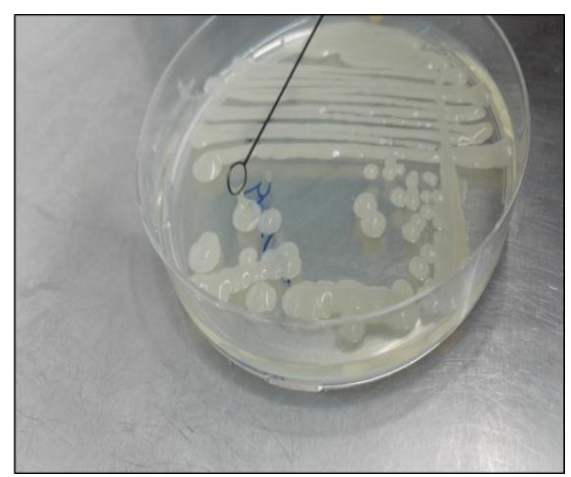

B: $5 \%$ sucrose nutrient agar

Fig.2: Colonies of $E$. amylovora. A: Characteristic crates observed on the surface of colonies, using (10X) magnification, B: The colonies shape of E. amylovora grown on SNA, typically yellow-white, domed, shiny and mucoid. 


\section{Biochemical characteristics}

The identification system API 20E was applied to all the isolates. The results were interpreted after $48 \mathrm{~h}$. at $26^{\circ} \mathrm{C}$. The isolates showed an identical API 20E profile number which was 0005522 Fig.3, this code number belong to E. amylovora according to (Mergaert et al., 1984). The same result was also recorded in Moropcco by (Ameur et al., 2014). They collected 402 strains of E. amylovora from different regions of pome fruit. Biochemical characterization of selected strains by API 20E system displayed quite homogeneous API 20E results, $80 \%$ of them exhibited the profile number 0005522 .

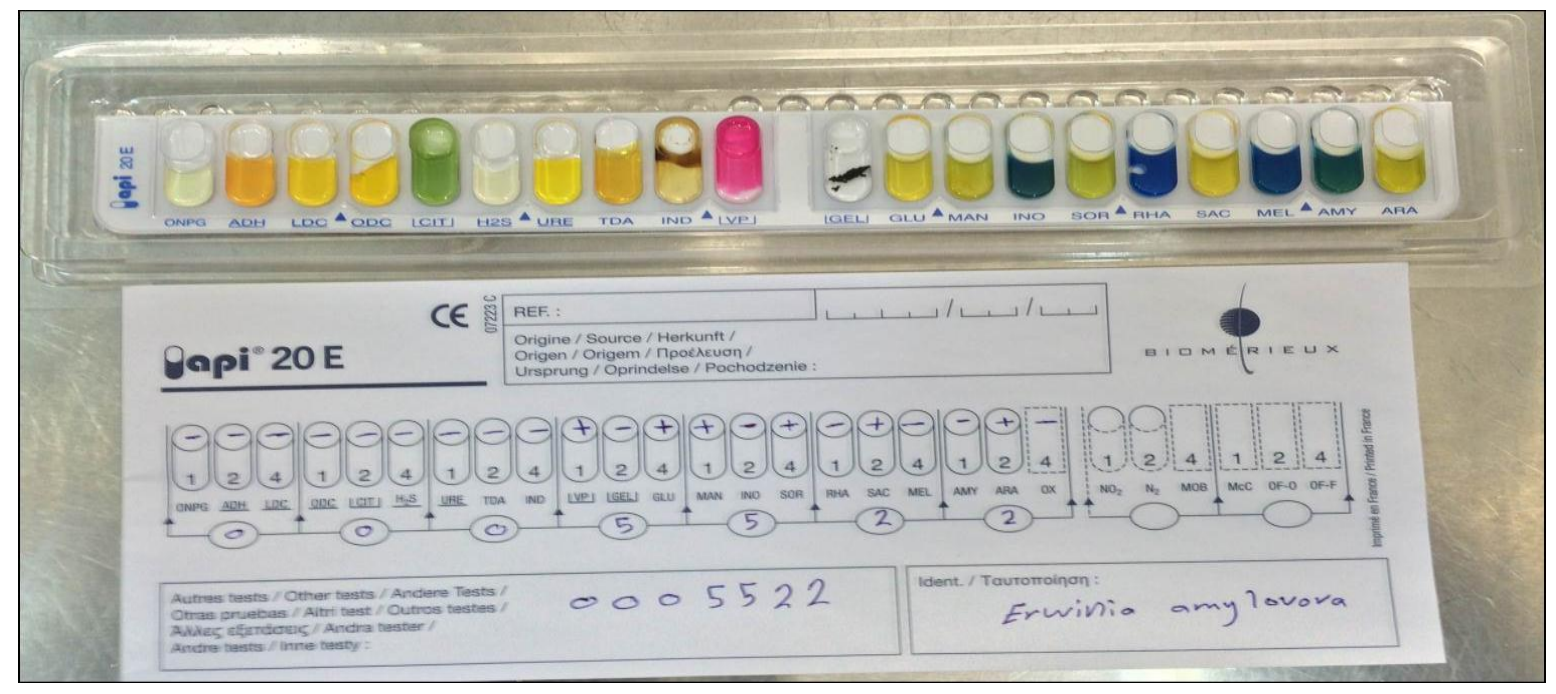

Fig. 3: The API 20E tests. Strip containing 20 tests and the profile sheet $(0005522)$ code numbers indicated that pathogen belong to $E$. amylovora

\section{Pathogenicity of E.amaylovora}

All isolates showed typical symptoms of the disease upon infection to immature pear fruits such as production of ooze on pear slices after five days with brownish Fig. (4 B), necrosis of leaves and shoots within 8-10 days. Necrotic spots appeared on the leaves starting from midribs and enlarged getting a triangle shape (Fig. 4 A). No symptoms were recorded in the case of control. The similar observations were also reported in Iran by (Kazempour et al., 2006).
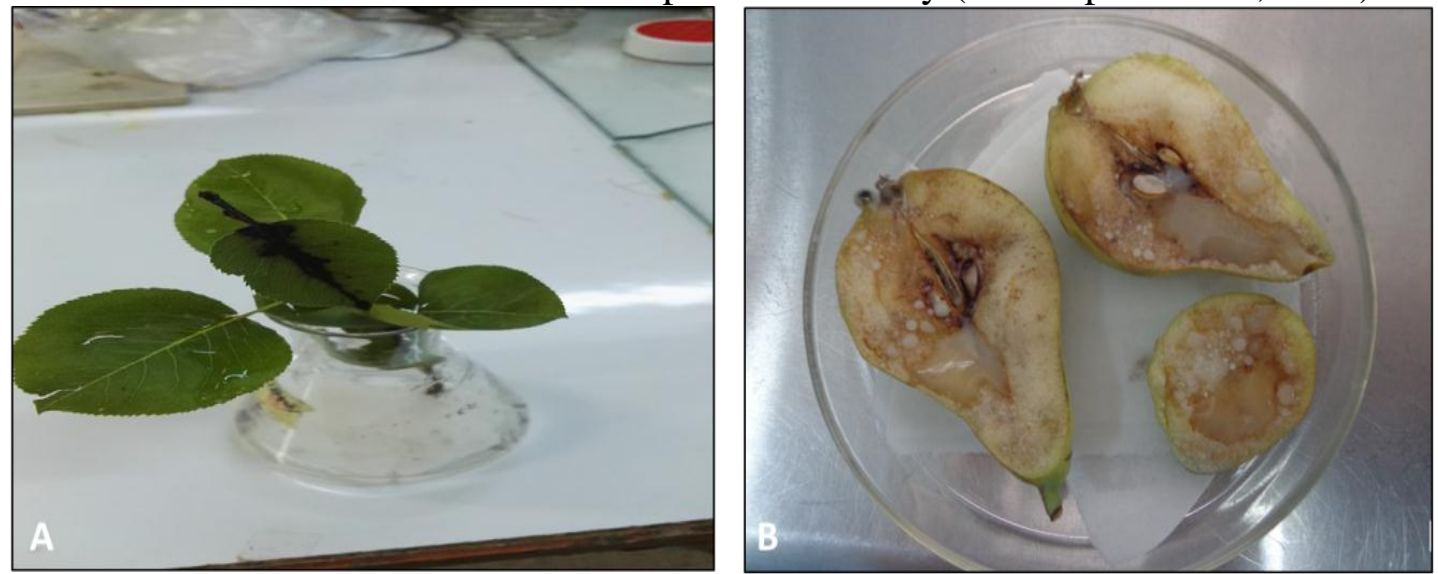

Fig. 4: Pathogenicity test for E. amylovora. A: Pear shoot inoculated with E. amylovora, necrosis of leaves and shoots started in the wound sites after 10 days. B: Bacterial ooze drop on pear slices after five days. 


\section{Molecular identification of E.amylovora isolates}

The results revealed that all E. amylovora isolates gave a positive response to the specific primer pEA71, which amplified a DNA fragment with expected size of $187 \mathrm{bp}$ during electrophoresis process within 1h., as it's illustrated in the figure the ladder is running 100bp for each band. Fig. (5).Our result was in agreement with (Taylor et al., 2001) who proved that pEA71 was universal for all known E. amylovora strains to date. These results were also reported in Morocco by (Ameur et al., 2014), where they identified 402 strains of E. amylovora. All strains reacted positively to specific primer (pEA71).

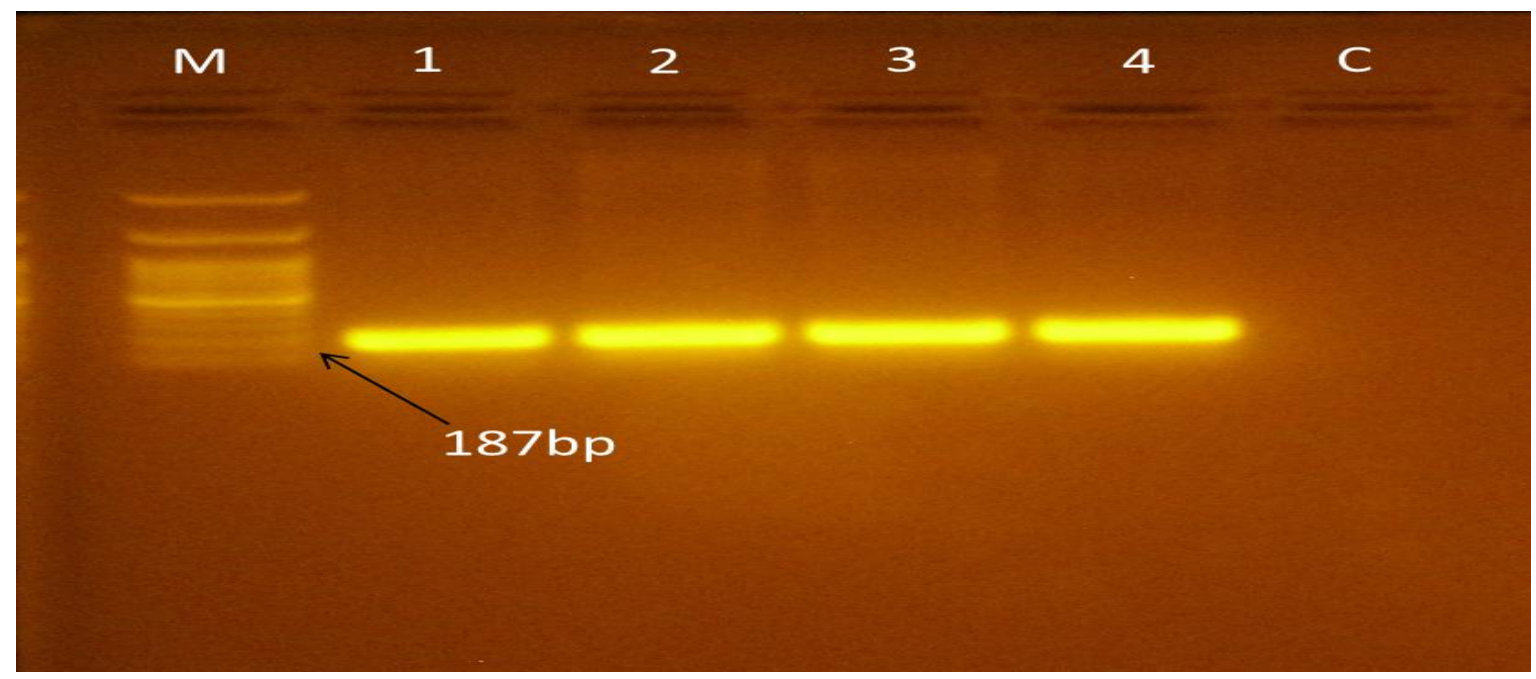

Fig. 5: Agarose gel (1\%) electrophoresis illustrating PCR products based on specific primer for E. amylovora. Lane M: 100 bp DNA Marker. Lanes 1 to 4; DNA of $E$. amylovora. Lane C: Negative control (PCR mixture without DNA).

\section{CONCLUSIONS}

Our study was carried out to investigate fire blight disease of pear and its causal pathogen, Erwinia amylovora. Symptoms were recognized and bacterial fire blight is not a widespread disease in Erbil province. Out of 9 localities, four isolates from one location in Choman area of different plant parts were identified. Detection of E. amylovora, applying PCR and the primer pEA71 is dependable method. The current study is the first identification and characterization of E. amylovora isolated from pear in Erbil Province.

\section{REFERENCES}

Ameur, A.; Ennaji, M.; Cesborn, S.; Manseau, C.H.; Rhallabi, N.; Achbani, H. (2014). Characterization of moroccan population of Erwinia Amylovora, the causal agent of fire blight on rosaceous. International J. Bioscience, Biochemistry and Bioinformatics, 4(3), 200-203.

Ammouneh, H.; Arabi, M.I.E.; AL-Daoude, A. (2008). The first record and distribution of fire blight pathogen Erwinia amylovora in Syria. Australasian Plant Pathology, 37(2), 137-140.

Anonymous, (2014). Nursery Production Threat specific contingency plan for fire blight, Queensland Department of Agriculture, Fisheries and Forestry November 2014 Australia.46pp.

Ashmawy, N.A.; Zaghloul, T.I.; EL-Sabagh, M.A. (2015). Isolation and molecular characterization of the fire blight pathogen, Erwinia amylovora, isolated from apple and pear orchards in Egypt. Plant Pathology J., 14(3), 142-147.

Atanasova, I.; Kabadjova, P.; Bogatzevska, N.; Moncheva, P. (2005). New host plants of Erwinia amylovora in Bulgaria. Zeitschrift fur Naturfors-chung C, 60(11-12), 893-898. 
Bastas, K.K. (2014). First report of fire blight First report of fire blight caused by Erwinia amylovora on Meadowsweet (Spirea prunifolia) in Turkey. The American Phytopathological Society. 98(1), 153.

Beer, S.V.; Rundle, J.R. (1983). Suppression of Erwinia amylovora by Erwinia herbicola in immature pear fruits. Phytopathology, 73, 1346.

Billing, E.; Baker, L.A.; Crosse, J.E.; Garrett, C.M. (1961). Characteristics of English isolates of Erwinia amylovora (Burrill) Winslow et al. J. Applied Bacteriol., 24, 195-211.

Burrill, T.J. 1883. New species of Micrococcus (bacteria). The American Naturalist, 17: 319.

Crosse, J.E.; Goodman, R.N. (1973). A selective medium for and a definitive colony characteristics of Erwinia amylovora, Phytopathology. 63, 1425-1426.

EUROPEAN AND MEDITERRANEAN PLANT PROTECTION ORGANIZATION(EPPO),(2004) Diagnostic protocols for regulated pests.OEPP/EPPO Bulletin,34,155-157.

Jones A.L. ; Geider K. (2001). Gram-negative bacteria, Erwinia amylovora group. In: Schaad N.W., Jones J.B., Chun W. (eds). "Laboratory Guide for Identification of Plant Pathogenic Bacteria". $3^{\text {rd }}$ ed, pp. 40-55. APS Press, St Paul, MN, USA.

Kaluzana, M.; Pulawska, J.; Mikicinski, A. (2013). Evaluation of methods for Erwinia amylovora detection. J. Horticultural Research. 21(2), 65-71.

Kazempour, M. N.; Kamran, E. ; ALI, B. (2006). Erwinia amylovora causing fire blight of pear in the Guilan province of Iran. J. Plant Pathology., 88(1), 113-116.

King, E.O.; Ward, M.K.; Raney, D.E. (1954). Two simple media for the demonstration of pyocyanin and fluorescin. J. Lab. Clin. Med., 44, 301-307.

Malika, Y.; M' Barek F.; Mohamed B.; Franko, V.; Giuseppe, S.; Anna, M.; D’onghia; Gabriella, C. (2011). Fire blight (Erwinia amylovora [Burrill] Winslow) in Morocco: Importance, geographical distribution and characterization, Phytopathol. Mediterr, 50, 212-227.

Mansfield, J.; Genin, S.; Magori, S.; Citovsky, V.; Sriariyanum, M.; Ronald, P.; Dow, M.; Verdier, V.; Machado, M.A.; Toth, I.; Salmond, G.; Foster, G.D. (2012). Top 10 plant pathogenic bacteria in molecular plant pathology. Mol. Plant Pathol., 13, 614-629.

Mergaert, J.; Verdonck, L.T.; Kersters, K.; Swings, J.; Boeufgras, J.M.; De Ley, J. (1984). Numerical taxonomy of Erwinia species using API systems. Jo. General Microbi., 130, 1893-1910.

Norelli, J.L.; Jones, A.L.; Aldwinckle, H.S. (2003). Fire blight management in the twenty-first century: using new technologies that enhance host resistance in apple. Plant Disease, 87,756-765.

Sambrook, J.; Fitgah, E.; Maniatis, T. (2000). "Molecular Cloning: A laboratory Manual". $3^{\text {rd }}$ ed. Cold spring, Harbor Laboratory, New York.

Severin, V.; Cornea, P.C. (2009). "Guidelines for Diagnosis of Plant Diseases". Edit. Ceres, Bucuresti: $279 \mathrm{p}$.

Taylor, R.K.; Guilford, P.J.; Clark, R.G.; Hale, C.N. ; Forster, R.L. (2001). Detection of Erwinia amylovora in plant material using novel polymerase chain reaction (PCR) primers. NZ. $J$. Crop Horticulturae Sci., 29, 35-43.

Van Der Zwet, T. (2006). Present worldwide distribution of fire blight a closely related diseases. (ISHS) Acta Horticulturae, 704, 35-36. 